\title{
Immune-mediated neutropenia and thrombocytopenia in a patient with ulcerative colitis: An unusual hematological association with IBD
}

\author{
YOUNG-IN KIM MD FRCPC, AARON BRZEZINSKI MD FRCPC, JOSEPH BRANDWEIN MD FRCPC, \\ JEFFREY P BAKER MD FRCPC
}

\begin{abstract}
Y-I KIM, A BRZEZINSKI, J BRANDWEIN, JP BAKER. Immune-mediated neutropenia and thrombocytopenia in a patient with ulcerative colitis: An unusual hematological association with IBD. Can J Gastroenterol 1995;9(2):96-100. Hematological manifestations of inflammatory bowel disease (IBD) are well described in the literature. However, the combination of immune-mediated neutropenia and thrombocytopenia has only been reported once in association with IBD. A case is reported of immune-mediated neutropenia and thrombocytopenia in a patient with ulcerative colitis during a relapse. No obvious causes of these hematological abnormalities were found in the patient despite an exhaustive search. An immune-mediated process was confirmed by positive antineutrophil antibody and platelet-associated antibody in the patient's serum, and the demonstration of binding of the patient's immunoglobulin $\mathrm{G}$ to autologous neutrophils. The patient was treated with high-dose steroid, intravenous gamma-globulin and eventually splenectomy. The platelet count subsequently normalized; although the severe neutropenia recurred, it has subsequently improved without further treatment. Although a definitive cause-effect relationship cannot be established, the immune-mediated neutropenia and thrombocytopenia may be an unusual hematological manifestation associated with ulcerative colitis. (Pour résumé, voir page 97)
\end{abstract}

Key Words: Immune-mediated, Inflammatory bowel disease, Neutropenia, Thrombocytopenia, Ulcerative colitis

Divisions of Gastroenterology and Hematology, Department of Medicine, St Michael's Hospital, University of Toronto, Toronto, Ontario

Correspondence: Dr Young-In Kim, Vitamin Bioavailability Laboratory, USDA Human Nutrition Research Center on Aging at Tufts University, 711 Washington Street, Boston, MA 02111, USA. Telephone (617) 556-3194, Fax (617) 556-3344

Received for publication June 5, 1994. Accepted June 20, 1994 Extraintestinal manifestations inflammatory bowel disease (IBD) and affect most organ systems of the body (1-5). Hematological complications occur in approximately $25 \%$ of IBD patients (6-17). Although thrombocytopenia has been described in up to $10 \%$ of patients with ulcerative colitis, there has been only one case reported in the literature of immune-mediated neutropenia and thrombocytopenia (17). Furthermore, there has been little documentation of the mechanisms leading to these hematological abnormalities. We report a case of immunemediated neutropenia and thrombocytopenia in a patient with ulcerative colitis during a period of relapse without evidence of other etiological factors.

\section{CASE PRESENTATION}

A 41-year-old Polish male with an eight-year history of ulcerative proctosigmoiditis presented with a onemonth history of malaise, fatigue, abdominal bloating, periumbilical pain 
Neutropénie et thrombocytopénie à médiation immunitaire chez un patient souffrant de colite ulcéreuse : signe hématologique inhabituel dans la MII

RÉSUMÉ : Les manifestations hématologiques de la maladie inflammatoire de l'intestin (MII) sont bien décrites dans la littérature. Toutefois, l'association d'une neutropénie et d'une thrombocytopénie à médiation immunitaire n'a été rapportée qu'une seule fois en lien avec la MII. Un tel cas est présenté ici chez un patient atteint de colite ulcéreuse, durant une rechute. Aucune cause évidente de telles anomalies hématologiques n'a été décelée chez le patient malgré une recherche approfondie. Un processus à médiation immunitaire a été confirmé par l'identification d'anticorps antineutrophiles et d'anticorps associés aux plaquettes dans le sérum du patient et la démonstration d'une liaison des immunoglobulines $G$ du patient aux neutrophiles autologues. Le patient a été traité par corticostéroïdes à fortes doses, par gamma-globulines intraveineuses et ensuite par splénectomie. La numération des plaquettes s'est par la suite normalisée. Bien qu'une neutropénie grave soit survenue, elle s'est par la suite améliorée sans traitement ultérieur. Même si l'on ne peut établir de façon définitive une relation de cause à effet, la neutropénie et la thrombocytopénie à médiation immunitaire peuvent être une manifestation hématologique inhabituelle associée à la colite ulcéreuse.

and up to 10 loose bowel movements daily with intermittent dark red blood. He complained of anorexia, weakness and postural lightheadedness. He also experienced intermittent nocturnal fever and had lost $13 \mathrm{~kg}$ of weight. He had no extraintestinal manifestations of ulcerative colitis during this period. There was no epistaxis, bleeding or purpura.

His ulcerative colitis had always been limited to the distal $15 \mathrm{~cm}$ of the colorectum and its course had been characterized by multiple exacerbations. Due to a poor response to oral sulfasalazine (up to $4 \mathrm{~g} /$ day), an enteric-coated delayed release form of mesalamine (Asacol; Procter \& Gamble) was substituted for sulfasalazine as induction and maintenance therapies five years prior to his current presentation. Since then, each exacerbation had been treated with oral Asacol up to $4 \mathrm{~g} /$ day and 5-aminosalicylic acid (5ASA) enemas (Salofalk; Interfalk Canada Inc) with a good response. He had been in remission for one year on Asacol $1.2 \mathrm{~g} /$ day up to the time of his presentation. He had never had any extraintestinal manifestations during the course of his disease. Since his first referral to the authors in 1984, his complete blood count $(\mathrm{CBC})$ had always been normal; six months prior to this presen- tation CBC showed hemoglobin 152 $\mathrm{g} / \mathrm{L}$, platelets $256 \times 10^{9} / \mathrm{L}$, white blood count (WBC) $6.3 \times 10^{9} / \mathrm{L}$ with a normal differential count, and erythrocyte sedimentation rate (ESR) $15 \mathrm{~mm} / \mathrm{h}$. He had never been transfused.

On examination, the patient appeared pale but there was no rash, ecchymosis or purpura. No lymphadenopathy was noted. His blood pressure was $100 / 60 \mathrm{mmHg}$ with mild postural drop and heart rate was 100 beats/min with postural tachycardia. His initial core body temperature was $37.0^{\circ} \mathrm{C}$. A few petechiae were seen on the palate but there were no bullous lesions. Abdominal examination revealed slight tenderness in left upper quadrant without peritoneal signs. There was no mass or hepatosplenomegaly. The rectal examination was normal. A flexible sigmoidoscopy revealed moderately active inflammation up to $60 \mathrm{~cm}$ and a sigmoid colon biopsy was consistent with active ulcerative colitis.

The patient was admitted to the hospital. Initial blood work showed hemoglobin $125 \mathrm{~g} / \mathrm{L}$, mean corpuscular volume (MCV) 79.9, platelets $26 \times 10^{9} / \mathrm{L}$, WBC $2.3 \times 10^{9} / \mathrm{L}$ (granulocytes $11 \%$, bands $2 \%$, lymphocytes $35 \%$, monocytes 30\%, eosinophils $21 \%$, basophils $1 \%$ ) and ESR $84 \mathrm{~mm} / \mathrm{h}$. The blood smear showed slight micro- cytosis, moderately decreased platelets, few tear drop cells and few fragments. Electrolytes, renal function, glucose, amylase and liver enzymes were normal. Total protein was $66 \mathrm{~g} / \mathrm{L}$ and albu$\min 30 \mathrm{~g} / \mathrm{L}$. Abdominal ultrasound and upper endoscopy were normal.

On the day of admission, the patient's temperature was up to $39.0^{\circ} \mathrm{C}$ without obvious source of infections except for a furuncle on the left buttock. The chest $\mathrm{x}$-ray was negative. Blood, urine, sputum and throat cultures were all negative. Stool cultures for bacteria, ova and parasites, and Clostridium difficile toxin were negative. Asacol was discontinued. The patient was started empirically on intravenous gentamicin, cefazolin and metronidazole but continued to run a low grade fever $\left(37.5\right.$ to $\left.38.0^{\circ} \mathrm{C}\right)$.

Bone marrow examination showed marked granulocytic hyperplasia up to the band stage with numerous megakaryocytes and normal erythroid activity. Iron stores were adequate and the marrow biopsy showed no evidence of infiltrative or myelodysplastic processes. Rheumatoid factor, antinuclear factor, and complement components 3 and 4 were normal. Direct and indirect Coombs' tests were negative. Prothrombin time, partial thromboplastin time and fibrinogen were normal, and fibrin degradation products were not elevated. Serum and erythrocyte folate and serum vitamin $B_{12}$ were normal. The serological test for the human immunodeficiency virus (HIV) by both ELISA and Western Blot done nine months later was negative. Serum immunoglobulin (Ig) $\mathrm{G}$ antineutrophil antibodies were positive by indirect assay using two normal donors; neutrophil count was too low for direct testing. Direct assay by flow cytometry showed positive platelet-associated (PA) IgG but negative PA IgM.

The patient's WBC remained around 1.0 to $1.5 \times 10^{9} / \mathrm{L}$ with an absolute neutrophil count (ANC) less than $0.25 \times 10^{9} / \mathrm{L}$. However, the platelet count continued to drop to $24 \times 10^{9} / \mathrm{L}$ on day 9 after admission. The patient was started on oral prednisone $80 \mathrm{mg} /$ day and his platelet count and WBC gradually increased (platelet count 


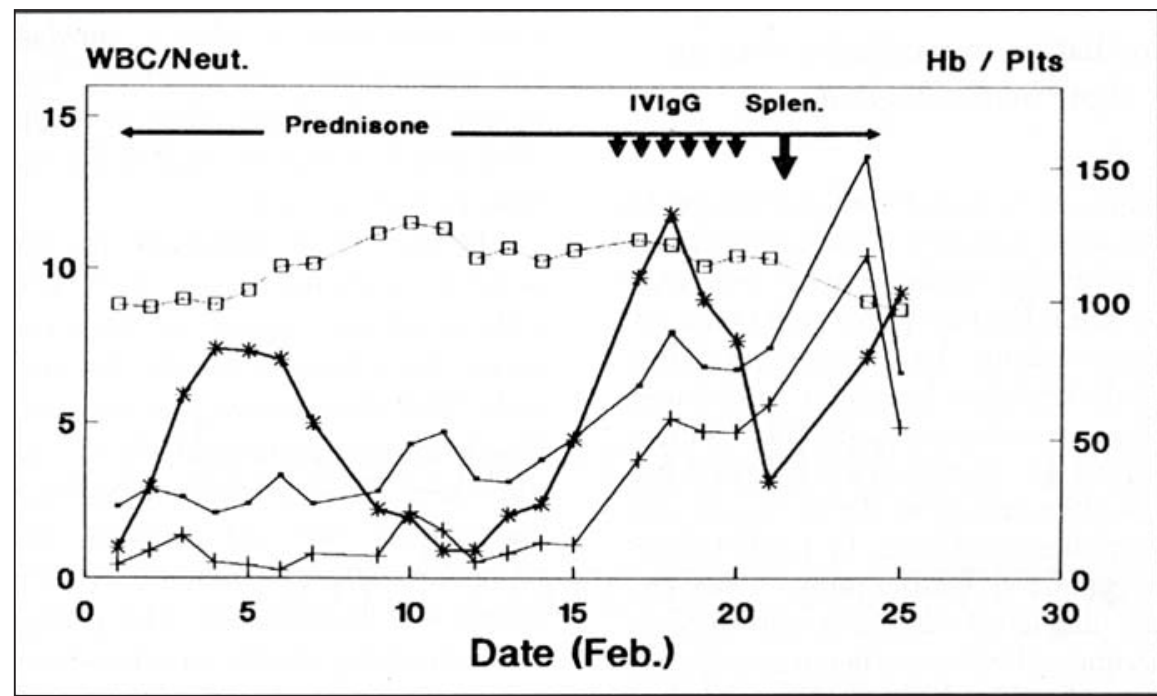

Figure 1) White blood cell (WBC) and platelet (Plts) count response to a high dose steroid, intravenous gamma-globulin and splenectomy (Splen). Ulcerative colitis was clinically active from day 1 to day 15. IVIgG Intravenous immunoglobulin G. - $\square-$ Hemoglobin $(\mathrm{Hb}) ;-+-$ Neutrophils (Neut); -* - Plts; —-WBC

$83 \times 10^{9} / \mathrm{L}$, WBC $2.1 \times 10^{9} / \mathrm{L}$ with ANC more than $0.5 \times 10^{9} / \mathrm{L}$ by day 12 ) (Figure 1). The patient defervesced and his constitutional and gastrointestinal symptoms all resolved within a few days after the initiation of prednisone.

However, on day 15, his platelet count began to drop and by day 18 it was $10 \times 10^{9} / \mathrm{L}$. The patient was started on intravenous gamma-globulin (Gamimune N; Miles Canada Inc) $0.4 \mathrm{~g} / \mathrm{kg}$ (total dose $30 \mathrm{~g}$ ) on day 20 , and oral prednisone was continued at $80 \mathrm{mg} /$ day with an increase in the platelet count $\left(86 \times 10^{9} / \mathrm{L}\right)$, WBC $\left(6.7 \times 10^{9} / \mathrm{L}\right)$ and ANC $\left(0.7 \times 10^{9} / \mathrm{L}\right)$ by day 24 .

On day 26, the patient underwent an uneventful splenectomy. He was continued on intravenous gammaglobulin up to the time of the operation. At laparotomy, the spleen was noted to be enlarged and microscopic examination showed perifollicular foamy macrophages in the splenic red pulp and the malpighian corpuscles and congestion of the splenic sinusoids. These changes were felt to be nonspecific.

Blood counts improved steadily on tapering doses of prednisone after splenectomy (Figure 1) and the patient was discharged home on day 32 with hemoglobin $97 \mathrm{~g} / \mathrm{L}$, WBC $6.6 \times 10^{9} / \mathrm{L}$ and platelet count $103 \times 10^{9} / \mathrm{L}$.

Prednisone was discontinued within two months of discharge. Asacol $2.4 \mathrm{~g} /$ day orally was reinstituted two months following discharge, and he has remained asymptomatic with no further gastrointestinal symptoms. His platelet count has remained above $100 \times 10^{9} / \mathrm{L}$ since splenectomy, with no PA IgG demonstrable at eight months follow-up. At most recent follow-up, 18 months postsplenectomy, his platelet count was $275 \times 10^{9} / \mathrm{L}$.

Neutropenia recurred two months postsplenectomy and the patient remained severely neutropenic for six months, with ANC less than $0.6 \times 10^{9} / \mathrm{L}$, although there was no evidence of a relapse of his ulcerative colitis. Since then, ANC has gradually risen without treatment, and is $1.85 \times 10^{9} / \mathrm{L}$ at 18 months postsplenectomy. At this time, serum that had been frozen early in his admission was thawed and tested against his own fresh neutrophils. Strong binding of IgG from his previously frozen serum to his fresh neutrophils was demonstrated by flow cytometry. At 18 months postsplenectomy, there was no binding of IgG or IgM from the patient's fresh serum to his own neutrophils.

\section{DISCUSSION}

More than 100 extraintestinal complications involving almost every organ system of the body have been de- scribed in IBD patients $(1,2)$. These manifestations occur frequently, often complicate management and are a significant source of morbidity and mortality (3).

Hematological abnormalities are seen in many IBD patients. These include iron deficiency anemia (6), folate and vitamin $B_{12}$ deficiency (7), Coombs' positive autoimmune hemolytic anemia $(8,9)$, thrombocytosis and impaired platelet function $(10,11)$, and thrombocytopenia (12-16). Thrombocytopenia in IBD may occur secondary to folate and/or vitamin B12 deficiency (12), megakaryocyte aplasia (13), immune thrombocytopenic purpura (14, $15)$ or drugs such as sulfasalazine (16).

As far as the combination of neutropenia and thrombocytopenia in IBD is concerned, a literature search using MEDLINE from 1966 to present revealed only one case report of a possible immune-mediated neutropenia and thrombocytopenia. Gupta et al (17) reported a man who developed sclerosing cholangitis, immune thrombocytopenic purpura (ITP) and neutropenia during the course of ulcerative colitis. This patient was on sulfasalazine when thrombocytopenia developed, but withdrawing it had no effect on platelet count. A bone marrow examination showed excessive numbers of megakaryocytes and IgG PA antibodies were present. He had two episodes of neutropenia; the first responding to an increased dose of prednisone and the second reverting spontaneously. Although antibodies against neutrophils were not measured in this case, it was concluded that there was transient immune neutropenia in association with ITP similar to one described previously (18).

Even though the pathogenesis of extraintestinal manifestations in IBD remains speculative (3), the most plausible explanation for these complications is related to immunological phenomena $(4,5)$. Therefore, it is surprising that immune-mediated hematological complications such as neutropenia and thrombocytopenia do not occur more often in patients with IBD. In contrast, isolated or concurrent immune-mediated destruction of plate- 
lets and neutrophils has been reported in several clinical settings where abnormalities in immune system are thought to play a major pathogenetic role such as collagen vascular diseases, drug reactions, malignancies and autoimmune disorders (19-27).

Our patient developed neutropenia and thrombocytopenia likely secondary to an immune-mediated process. The presence of PA $\operatorname{IgG}$, and the demonstration of binding of the patient's IgG to autologous neutrophils, provide strong evidence for an autoimmune etiology for these cytopenias.

The bone marrow was consistent with peripheral consumption of both mature neutrophils and platelets, with no evidence of a marrow disorder. Although a marrow karyotype was not performed, the diagnosis of myelodysplasia is extremely unlikely, given the subsequent normalization of the platelet count and later marked improvement of the neutrophil count. Other possible causes for consumptive neutropenia and thrombocytopenia such as infections or disseminated intravascular coagulation were excluded. The patient had neutropenic fever without obvious sources of infections and it is unlikely that he had an overwhelming infection causing neutropenia and thrombocytopenia. Other causes for autoimmune neutropenia and thrombocytopenia, such as HIV infection, collagen vascular diseases, malignancy and drugs, were excluded. In particular,

\section{REFERENCES}

1. Rankin GB. Extraintestinal and systemic manifestations of inflammatory bowel disease. Med Clin North Am 1990;74:39-50.

2. Greenstein AJ, Janowitz HD, Sachar DB. The extraintestinal complications of Crohn's disease and ulcerative colitis. A study of 700 patients. Medicine 1976;55:401-12.

3. Kirsner JB. Inflammatory bowel disease: Considerations of etiology and pathogenesis. Am J Gastroenterol 1978;65:253-71.

4. Present DH. Extraintestinal manifestations. Mt Sinai J Med 1983;50:126-32.

5. Rankin GB, Watts HD, Melnyk CS, Kelley ML Jr. National cooperative Crohn's disease study: Extraintestinal manifestations and perianal the HIV testing (ELISA and Western Blot) performed nine months after his acute illness and cytopenias essentially ruled out HIV infection.

Furthermore, we do not believe that there is an etiological link between Asacol and his hematological abnormalities for the following reasons: he had been using Asacol over five years without any hematological complications; his platelet and neutrophil counts did not recover following cessation of Asacol; his neutrophil and platelet counts were decreasing even before Asacol was reinstituted after his discharge from the hospital; and his neutrophil and platelet counts have gradually normalized over the 18 -month follow-up while on Asacol.

In addition, his transient response to high dose steroids, intravenous gamma-globulin and splenectomy provide further evidence for an immunemediated process as the primary culprit. Therefore, the most likely precipitating factor in this case was the patient's underlying ulcerative colitis which was active and had extended proximally as documented by endoscopic investigations when he first developed neutropenia and thrombocytopenia.

The initial response to splenectomy in our patient was encouraging. However, the fact that the neutrophil count subsequently returned to baseline suggests that the gamma-globulin, and not splenectomy, was responsible for the transient response in the neutrophil

complications. Gastroenterology 1979;77:914-20.

6. Dyer NH, Child JA, Mollin DL, Dawson AM. Anemia in Crohn's disease. Q J Med 1972;41:419-36.

7. Elsborg L, Larsen L. Folate deficiency in chronic inflammatory bowel disease. Scand J Gastroenterol 1979;14:1019-24.

8. Allan RN. Extraintestinal manifestations of inflammatory bowel disease. Clin Gastroenterol 1983;12:617-32.

9. Talbot RW, Heppell J, Dozois RR, Beart RW Jr. Vascular complications of inflammatory bowel disease. Mayo Clinic Proc 1986;61:140-5.

10. Lake AM, Stauffer JQ, Stuart MJ. Hemostatic alterations in inflammatory bowel disease: Response to therapy. Am J Dig Dis 1978;23:897-902. count. Intravenous gamma-globulin has been reported to be effective in autoimmune neutropenia $(19,28)$ whereas response rates to splenectomy in immune neutropenia have been reported to be about $50 \%$. On the other hand, splenectomy was most likely responsible for the sustained platelet response in this patient because the platelet response to intravenous $\operatorname{IgG}$ is usually transient (19).

It is interesting to note that the patient's neutrophil count has gradually risen to normal without further treatment, and that he no longer demonstrates serum antineutrophil antibodies. The disappearance of antineutrophil antibodies in association with remission of autoimmune neutropenia has been described (20). Whether this is related to removal of a major site of antibody production with splenectomy in our patient, remission of his underlying IBD or some other cause, is unknown.

In summary, we report a case of immune-mediated neutropenia and thrombocytopenia in a patient with ulcerative colitis during a relapse without evidence of other causative factors. He remains slightly neutropenic without any clinical consequence. We suggest that immune-mediated neutropenia and thrombocytopenia is an unusual hematological complication associated with ulcerative colitis.

11. Talstad I, Rootwell K, Gjore E. Thrombocytosis in ulcerative colitis and Crohn's disease. Scand J Gastroenterol 1973;8:135-8.

12. Keene WR. Uncommon abnormalities of blood associated with chronic ulcerative colitis. Med Clin North Am 1966;50:535-41.

13. Fox RM, Firkin FC. Sequential pure red cell and megakaryocytic aplasia associated with chronic liver disease and ulcerative colitis. Am J Hematol 1978;4:79-85.

14. Edwards FC, Truelove SC. The course and prognosis of ulcerative colitis 3 . Complications. Gut 1964;5:1-22.

15. Kocoshis SA, Gartner JC Jr. Gaffney PC, Gryboski JD. Thrombocytopenia in ulcerative colitis. J Pediatr 1979;95:83-4.

16. Gremse DA, Bancroft J, Moyer MS. 
Sulfasalazine hypersensitivity with hepatotoxicity, thrombocytopenia and erythroid hyperplasia. J Pediatr Gastroenterol Nutr 1989;9:261-3.

17. Gupta S, Saverymuttu SH, Marsh JCW, Hodgson HJ, Chadwick VS. Immune thrombocytopenic purpura, neutropenia and sclerosing cholangitis associated with ulcerative colitis in an adult. Clin Lab Haematol 1986;8:67-9.

18. Linker CA, Newcom SR, Nilsson CM, Wolfe JL, Shuman MA. Combined idiopathic neutropenia and thrombocytopenia. Ann Intern Med 1980;93:704-7.

19. Novak RM, Ou DW. Variable response to intravenous gamma-globulin treatment in a patient with autoimmune neutropenia, thrombocytopenia and pemphigoid. South Med J 1988;81:653-5.
20. Bux J, Robertz-Vaupel GM, Glasmacher A, Dengler HJ, Mueller-Eckhardt C. Autoimmune neutropenia due to NAI specific antibodies in primary biliary cirrhosis. Br J Hematol 1991;77:121-2.

21. Weitberg AB, Harmon DC. Autoimmune neutropenia, hemolytic anemia and reticulocytopenia in Hodgkin's disease. Ann Intern Med 1984;100:702-3.

22. Kruskall MS, Weitzman SA, Stossel TP, Harris N, Robinson SH. Lymphoma with autoimmune neutropenia and hepatic sinusoidal infiltration: A syndrome. Ann Intern Med 1982;97:202-5.

23. Bluming AZ, Plotkin D. Severe transient pancytopenia associated with procainamide ingestion. JAMA 1976;236:2520-1.

24. Castro O, Nash I. Quinidine leukopenia and thrombocytopenia with a drug-dependent leukoagglutinin. $\mathrm{N}$ Engl J Med 1977;296:572.

25. Barnes CG, Turnbull AL,

Vernon-Roberts B. Felty's syndrome: A

clinical and pathological survey of 21 patients and their response to treatment. Ann Rheum Dis 1971;30:359-74.

26. Fagiolo E. Platelet and leucocyte antibodies in autoimmune hemolytic anemia. Acta Hematol 1976;56:97-106.

27. Budwan DR, Steinberg AD.

Hematologic aspects of systemic lupus erythematosus: Current concepts. Ann Intern Med 1977;86:220-9.

28. Pollack S. High dose intravenous gamma-globulin for autoimmune neutropenia. N Engl J Med 1983;307:253. 


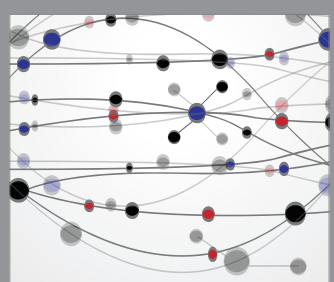

The Scientific World Journal
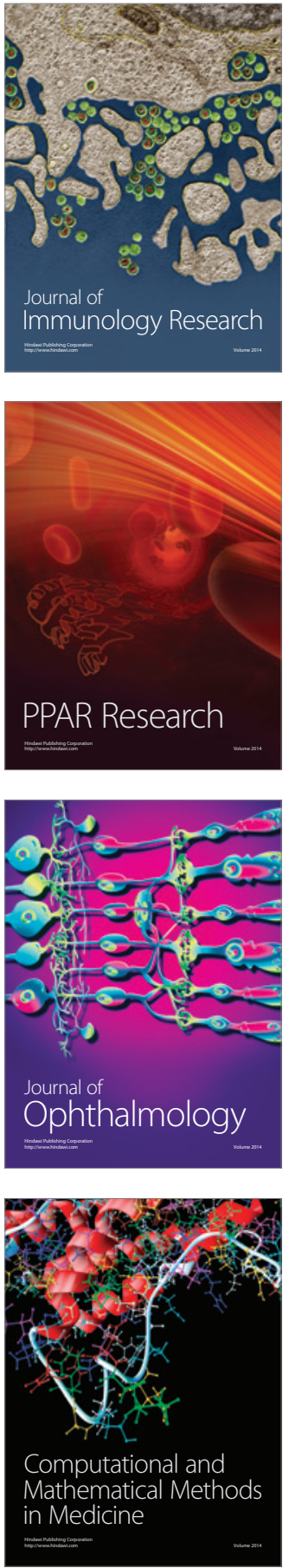

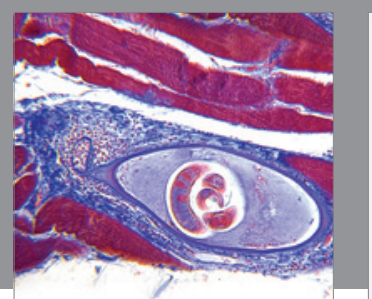

Gastroenterology Research and Practice

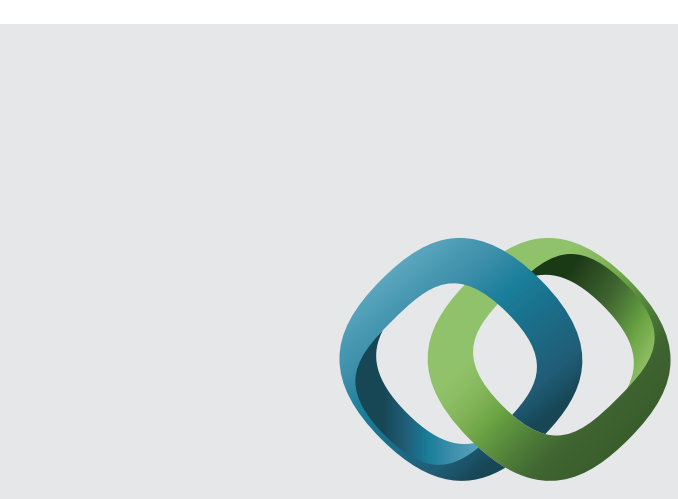

\section{Hindawi}

Submit your manuscripts at

http://www.hindawi.com
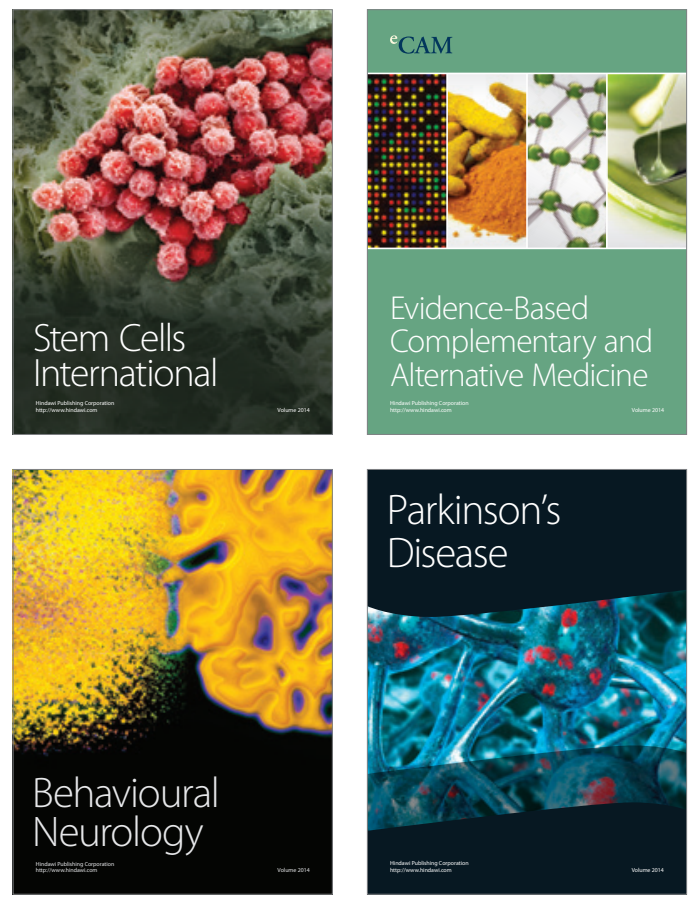
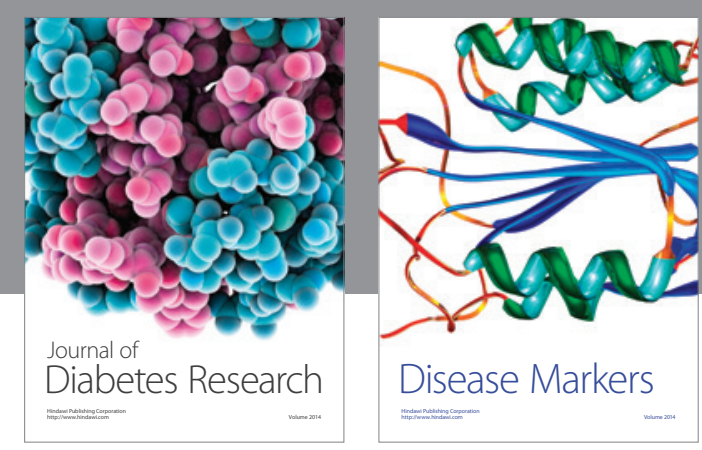

Disease Markers
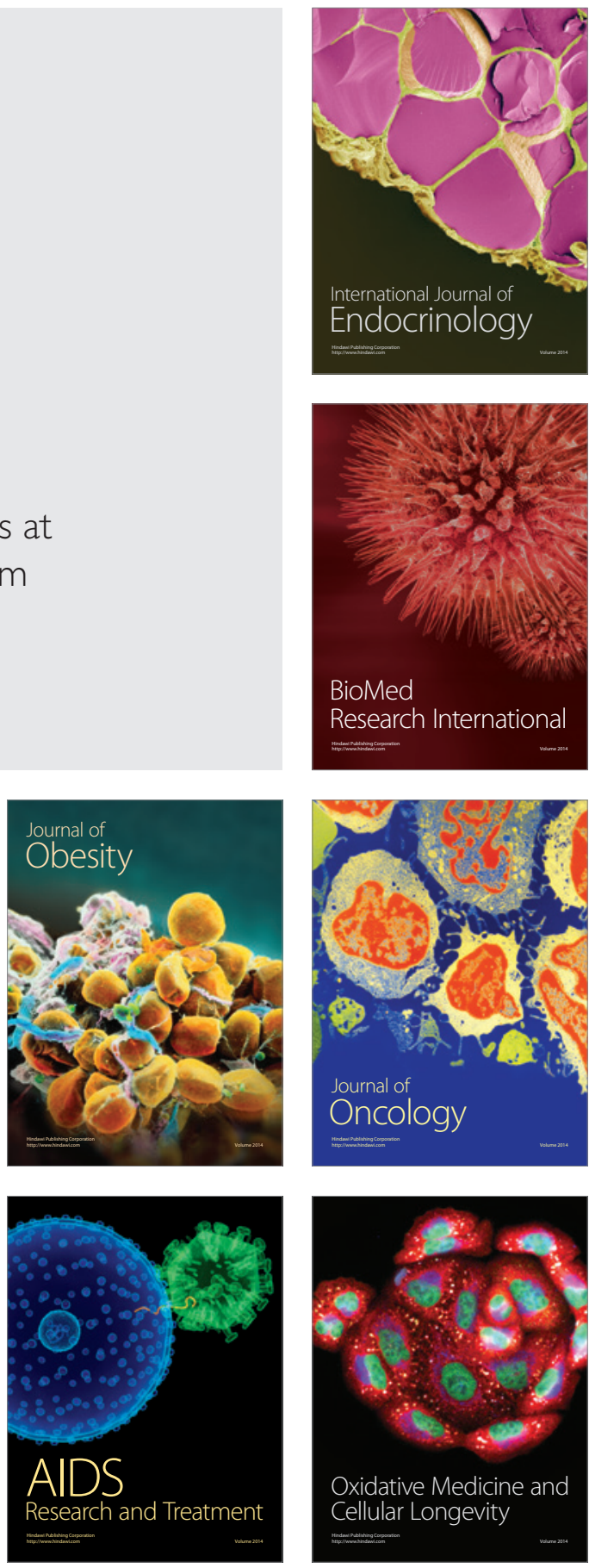